\section{Flowering of Anthurium following Treatment with Gibberellic Acid}

\author{
R.J. Henny and R.L. Hamilton ${ }^{1}$ \\ University of Florida, Institute of Food and Agricultural Sciences, \\ Central Florida Research and Education Center, 2807 Binion Road, \\ Apopka, FL 32703
}

Additional index words. Anthurium scherzeranum, foliage plant, growth regulator, light intensity, $\mathrm{GA}_{3}$

Anthuriums are becoming popular "flowering" foliage plants as growers look for new crops to expand their markets. Advantages of anthurium are that they can be grown in environments similar to many other foliage plants, liners from tissue culture are available year round, attractive inflorescences can be produced continually under greenhouse conditions, and new cultivars developed for pot culture are becoming available.

Anthurium inflorescences are normally produced by a dominant central stem initially and later by lateral stems, if produced. Cultivars with many lateral shoots, while desirable for pot culture, tend to flower later than those with strong apical dominance. Stimulating earlier flowering of lateral shoots could result in shorter production time and higher flower counts. Therefore, the following experiments were conducted using gibberellic acid $\left(\mathrm{GA}_{3}\right)$ in an attempt to increase flower production of anthuriums. $\mathrm{GA}_{3}$ was chosen because it has been used previously to stimulate flowering of several other ornamental aroids (Henny, 1980, 1981, 1983).

The first experiment was conducted using 105 plants of $A$. scherzeranum 'Amazone', 28 weeks from tissue culture, $\approx 10 \mathrm{~cm}$ high, and growing in 10 -cm-diameter (0.45-liter) pots filled with a 1 pine bark : 1 Vergro Container Mix A (v/v) (Verlite Co., Tampa, Fla.). Plants were placed in a randomized block design in a shaded greenhouse with a temperature range of 18 to $32 \mathrm{C}$ and 110 umol $\cdot \mathrm{m}^{-2} \cdot \mathrm{s}^{-1}$ maximum light intensity under natural photoperiod in Apopka, Fla. Plants were fertilized with $2.5 \mathrm{~g}$ of 19-6-12 (N$\mathrm{P}_{2} \mathrm{O}_{5}-\mathrm{K}_{2} \mathrm{O}$ ) Osmocote per pot applied on the soil surface. Gibberellic acid (ProGibb, Abbott Laboratories, North Chicago) was applied at $0,12.5,250,375$, or $500 \mathrm{mg}$ a.i./

Received for publication 17 Apr. 1992. Accepted for publication 8 July 1992. Florida Agricultural Experiment Stations Journal Series no. R-02318. The cost of publishing this paper was defrayed in part by the payment of page charges. Under postal regulations, this paper therefore must be hereby marked advertisement solely to indicate this fact. 'Twyford Plant Labs, 4051 Fudge Road, Apopka, FL 32712. Current address: MetroLab Inc., 16400 Huntersville-Concord Rd., Huntersville, NC 28078. are from two separate experiments. liter as a single foliar spray on 18 Nov. 1988. A total of $200 \mathrm{ml}$ of solution was used to treat 21 plants at each $\mathrm{GA}_{3}$ level. Final data regarding flowering were taken after $\approx 4$ months (13 Mar.).

The second experiment involved 180 plants of $A$. scherzeranum 'Renate', 28 weeks from tissue culture, and growing in 10-cm-diameter $(0.45$-liter) pots. Ninety plants were placed in a randomized block design under natural photoperiod at a maximum light intensity of $170 \mu \mathrm{mol} \cdot \mathrm{m}^{-2} \cdot \mathrm{s}^{-1}$ and 90 plants at $280 \mu \mathrm{mol} \cdot \mathrm{m}^{-2} \cdot \mathrm{s}^{-1}$ in a shaded greenhouse with a temperature range of 18 to $32 \mathrm{C}$. The potting medium was as noted, and fertilization consisted of 150 to $200 \mathrm{mg}$ water-soluble 9-3-6 ( $\left.\mathrm{N}-\mathrm{P}_{2} \mathrm{O}_{5}-\mathrm{K}_{2} \mathrm{O}\right)$ fertilizer/liter applied at each watering. Plants received a single foliar spray of $\mathrm{GA}_{3}$ at the same concentrations used in the first experiment; however, in this test 18 plants were sprayed with $200 \mathrm{ml}$ of solution at each $\mathrm{GA}_{3}$ level. Plants were treated 5 May 1989, and final data were collected 3 months later (8 Aug.).

In the first experiment, 'Amazone' treated with $\mathrm{GA}_{3}$ produced significantly more flowers, but the increase was small (Table 1). There was little difference in bloom count due to treatment rate. In the second experiment, 'Renate' grown at low light intensity responded similarly to 'Amazone' by pro- ducing a significant, although slight, increase in blooms. 'Renate' grown at high light and receiving high $\mathrm{GA}_{3}$ levels (375 or $500 \mathrm{mg} \cdot \mathrm{liter}^{-1}$ ) had high bloom counts (Table 1).

In these experiments, 'Amazone' and 'Renate' grown at light levels of 110 or 170 $\mu \mathrm{mol} \cdot \mathrm{m}^{-2} \cdot \mathrm{s}^{-1}$, respectively, showed a small but significant increase in flowering following $\mathrm{GA}_{3}$ treatment. This response was of little commercial value however. Growing 'Renate' at $280 \mu \mathrm{mol} \cdot \mathrm{m}^{-2} \cdot \mathrm{s}^{-1}$ light intensity before and after treatment resulted in higher bloom counts at all $\mathrm{GA}_{3}$ levels; plants treated with 375 or $500 \mathrm{mg} \mathrm{GA} /$ /iter averaged more than three blooms per pot. Blooms were produced by the central shoot and lateral shoots. Anthurium andraeanum Linden produced more blooms when grown under higher light intensity (Leffring, 1975), while a separate report showed that a spray of $100 \mathrm{mg} \mathrm{GA}_{3} /$ liter had no effect on flowering (Nakasone and Kamemoto, 1962). Those reports plus the results from the two experiments reported here indicate that light intensity and $\mathrm{GA}_{3}$ concentration are important factors in regulating Anthurium bloom count.

\section{Literature Cited}

Henny, R.J. 1980. Gibberellic acid $\left(\mathrm{GA}_{3}\right)$ induces flowering in Dieffenbachia maculata 'Perfection'. HortScience 15:613.

Henny, R.J. 1981. Promotion of flowering in Spathiphyllum 'Mauna Loa' with gibberellic acid. HortScience 16:554-555.

Henny, R.J. 1983. Flowering of Aglaonema commutatum 'Treubii' following treatment with gibberellic acid. HortScience 18:374.

Leffring, L. 1975. Influence of climatical conditions on growth and flower yield of Anthurium andraeanum. Acta Hort. 51:63-68.

Nakasone, H.K. and H. Kamemoto. 1962. Anthurium culture with emphasis on effects of some induced environments on growth and flowering. Hawaii Agr. Expt. Sta. Tech. Bul. 50, Honolulu.

Table 1. Effect of light levels and $\mathrm{GA}_{3}$ concentrations (applied as a single foliar spray) on the mean number of inflorescences produced by two Anthurium scherzeranum cultivars. The data presented

\begin{tabular}{|c|c|c|c|}
\hline \multirow{4}{*}{$\begin{array}{l}\mathrm{Ga}_{3} \text { concn } \\
\left(\mathrm{mg} \cdot \mathrm{liter}^{-1}\right)\end{array}$} & \multicolumn{3}{|c|}{ Cultivar } \\
\hline & Amazone $^{z}$ & \multicolumn{2}{|c|}{ Renate $^{y}$} \\
\hline & \multicolumn{3}{|c|}{ Light intensity $\left(\mu \mathrm{mol} \cdot \mathrm{m}^{-2} \cdot \mathrm{s}^{-1}\right)$} \\
\hline & 110 & 170 & 280 \\
\hline 0 & 0.2 & 0.2 & 0.3 \\
\hline 125 & 1.8 & 0.2 & 1.4 \\
\hline 250 & 2.0 & 0.6 & 1.9 \\
\hline 375 & 1.6 & 1.2 & 3.3 \\
\hline 500 & 1.7 & 1.3 & 5.3 \\
\hline \multicolumn{4}{|l|}{ Significance } \\
\hline Concn, linear & * & * & $*$ \\
\hline Concr, quadratic & * & NS & NS \\
\hline Concn $\times$ light & --- & * & $*$ \\
\hline
\end{tabular}

${ }^{z_{n}}=21$. Plants treated 18 Nov. 1988 and flowers counted 13 Mar. 1989.

$\mathrm{y}_{\mathrm{n}}=18$. Plants treated 5 May 1989 and flowers counted 8 Aug. 1989.

NS,*Nonsignificant and significant at $P=0.05$, respectively. 